\title{
Synthesis of some Heterocyclic compounds bearing Coumarin nucleus and their Anti-inflammatory activity
}

\author{
Nadia T. A. Dawoud ${ }^{1 *}$, Nahed.F.Abdel-Ghaffar ${ }^{2}$, Mona M Abdl-galil ${ }^{3}$, Fekria M. A. Soliman ${ }^{4}$, \\ Heba M Zaki ${ }^{5}$ \\ ${ }^{1-5}$ Department of Chemistry, Faculty of Science (Girls), Al-Azhar University, Nasr City, Cairo, Egypt \\ ${ }^{*}$ Corresponding author: E-mail:dawoudnadia@yahoo.com
}

\section{ABSTRACT}

Starting from 6-amino-4-methyl-2H-chromen-2-one 1, a series of some new heterocyclic compounds (2-14) incorporating coumarin moiety was synthesized and assessed for their anti-inflammatory activity using the carrageenan-induced hind paw edema method. The tested coumarin derivatives reduce the edema volume and serum levels of the pro inflammatory cytokines, IL- 6 and TNF- $\alpha$, and have effects on promoting production of anti-inflammatory cytokine, IL-10.

KEYWORDS: 6-amino-4-methylcoumarin, Multi-component reactions, Microwave irradiation assistant, Antiinflammatory Activity.

\section{INTRODUCTION}

The synthesis of coumarins and their derivatives has attracted considerable attention from organic and medicinal chemists for many years as a large number of natural and synthetic products contain this heterocyclic nucleus [1-5]. A number of natural and synthetic coumarin derivatives have been reported to exert notable antimicrobial $[1,2]$, antifungal $[3,4]$ and cytotoxic [5] activity. Furthermore it has been reported by different scientists that coumarin derivatives incorporating, pyrazole, thiazole, oxazole pyridine, pyrimidine and 1,3-oxazepine derivatives have also attracted increasing attention due to their numerous pharmacological applications and biological activities, such as anti-inflammatory, analgesic, antimicrobial, anti-HIV, anti-hypertensive and herbicidal activity [6-10]. MCRs comply with the principles of green chemistry in terms of economy of steps as well as many of the stringent criteria of an ideal organic synthesis. In view of these observations and in continuation of our previous work on the synthesis of heterocyclic systems and biological evaluation [11, 12], we report herein a facile route to various heterocyclic derivatives incorporating coumarin moiety .Additionally, we have found that synthesized compounds have shown anti-inflammatory activity.

\section{EXPERIMENT}

All melting points are not corrected. The infrared spectra on $\mathrm{KBr}$ disks were carried on a Pye Unicam $\mathrm{SP}^{3}-200$ spectrophotometer. The NMR Spectra were measured on a varian EM 60 and JE OL $-90 \mathrm{MHz}$ Spectrometers with TMS as internal reference, chemical shifts were expressed in $\delta \mathrm{ppm}$. The mass spectra were determined on a FINNI - Gas 3300 mass spectrometer by direct inlet (Source temperature $90-300 \stackrel{\circ}{C}$, beam energy 70 (ev).

\section{GENERAL PROCEDURE}

\section{Synthesis of 6-amino-4-methyl-2H-chromen-2-one 1}

A mixture of 4-amino phenol $(0.01 \mathrm{~mole} ; 1.09 \mathrm{gm}),(0.01 \mathrm{~mol})$ of ethylacetoacetate in concentrated $\mathrm{H}_{2} \mathrm{SO}_{4}(25 \mathrm{ml})$ was heated with stirring on water bath for half an hour. The reaction product was poured onto ice/cold water; the solid that separated was recrystallized from ethanol to give 6-amino-4-methyl-2H-chromen-2-one 1.

1 as gray crystals, in $70 \%$ yield, m. p $252{ }^{\circ} \mathrm{C}$; anal calc for $\mathrm{C}_{10} \mathrm{H}_{9} \mathrm{NO}_{2}(175)$ : C, 68.57; $\mathrm{H}, 5.14 ; \mathrm{N}, 8.00$;O,18.29: Found; $\mathrm{C}, 68.55 ; \mathrm{H}, 5.13 ; \mathrm{N}, 7.98 ; \mathrm{O}, 18.26$. IR $\left(\mathrm{cm}^{-1}\right): 3345.50-3295.77\left(\mathrm{NH}_{2}\right), 1743.76 \mathrm{~cm}^{-1}$ (CO, Lactone) and $1366.71 \mathrm{~cm}^{-1}\left(\mathrm{CH}_{3}\right)$. $\delta \mathrm{H}: 4.930\left(2 \mathrm{H}, \mathrm{s}, \mathrm{NH}_{2}\right), 6.844\left(1 \mathrm{H}, \mathrm{s}, \mathrm{C}=\mathrm{CH}\right.$, Coumarin), $7.230-7.155(3 \mathrm{H}, \mathrm{m}, \mathrm{Ar}-\mathrm{H}), 1.264\left(3 \mathrm{H}, \mathrm{s}, \mathrm{CH}_{3}\right) .{ }^{13} \mathrm{C}-\mathrm{NMR}$ spectrum (400 MHz, DMSO-d6, $\delta, \mathrm{ppm})$ : $153.006(\mathrm{C}=\mathrm{O}), 125.743(\mathrm{C}=\mathrm{C}), 117.724(\mathrm{C}-\mathrm{CH} 3), 121.86(\mathrm{CH}-\mathrm{C}=\mathrm{O}), 125.781(\mathrm{C}-$ $\mathrm{H}), 131.386(\mathrm{C}-\mathrm{N})$.

\section{Synthesis of 4-methyl-6-\{[(Z)-(3-aryl derivatives)methylidene]amino\}-2H-chromen-2- one 2a-d}

To ethanolic solution of 1 (0.01 mole; $1.75 \mathrm{gm})$,different aromatic aldehydes namely, cinnamaldehyde, 3 nitrobenzaldehyde, 4-methoxybenzaldehyde $(0.01 \mathrm{~mole})$, terphthalaldehyde $(0.02 \mathrm{~mole})$ were added in the presence of catalytic amount of glacial acetic acid,. The reaction mixture was heated under reflux for 6 hrs. The produced precipitate was filtered off on hot, collected, and recrystallised from ethanol to give 2a-d.

2a Orange powder, $80 \%$ yield, m.p. $165^{\circ} \mathrm{C}$; Anal. Calcd for $\mathrm{C}_{19} \mathrm{H}_{15} \mathrm{NO}_{2}(289)$ : $\mathrm{C}, 78.89 ; \mathrm{H}, 5.19 ; \mathrm{N}, 4.84$ : Found; $\mathrm{C}, 78.86 ; \mathrm{H}, 5.17 ; \mathrm{N}, 4.82$. IR $\left(\mathrm{cm}^{-1}\right): 1750.0\left(\mathrm{C}=\mathrm{O}\right.$, Lactone) , $1604.00(\mathrm{C}=\mathrm{N}), 1448.70\left(\mathrm{CH}_{3}\right) . \mathrm{MS}(\mathrm{m} / \mathrm{z}, \%), 289(0.45 \%)$. $\delta \mathrm{H}: 1.239\left(3 \mathrm{H}, \mathrm{s}, \mathrm{CH}_{3}\right), 6.891(1 \mathrm{H}, \mathrm{s}, \mathrm{CH}$-Coumarin), 7.82-7.71(8H, m, Ar-H), 7.99(1H, s, $\mathrm{CH}=\mathrm{N}-)$ and $7.24-7.00(2 \mathrm{H}, \mathrm{d}$, $\mathrm{CH}=\mathrm{CH}$-ethylenic).

2b Brown powder in $70 \%$ yield, m.p. $172^{\circ} \mathrm{C}$; anal calc for $\mathrm{C}_{17} \mathrm{H}_{12} \mathrm{~N}_{2} \mathrm{O}_{4}(308)$ : C, 66.23; H, $3.89 ; \mathrm{N}, 9.09$ :Found; C, $66.21 ; \mathrm{H}$, 3.87; N, 9.06. IR $\left(\mathrm{cm}^{-1}\right): 1750.00(\mathrm{CO}$, Lactone $), 1642.6,(\mathrm{C}=\mathrm{N}), 1366.70\left(\mathrm{CH}_{3}\right)$. 
2c Dark brown powder in $70 \%$, m.p. $190^{\circ} \mathrm{C}$;anal calc for ${ }_{18} \mathrm{H}_{15} \mathrm{NO}(293)$ : C,67.51; $\mathrm{H}, 4.17 ; \mathrm{N}, 5.08$;Found:C,67.50; $\mathrm{H}, 4.16$; N,5.90. IR (cm-1):1728.57(CO, Lactone), $1616.5(\mathrm{C}=\mathrm{N}), 1374.40\left(\mathrm{CH}_{3}\right) . \delta \mathrm{H}: 1.246\left(3 \mathrm{H}, \mathrm{s}, \mathrm{CH}_{3}\right), 3.93(3 \mathrm{H}, \mathrm{s}, \mathrm{OCH})$, 6.89(1H, s, CH-Coumarin), 8.22(1 $\mathrm{H}, \mathrm{s}, \mathrm{CH}=\mathrm{N}-)$ and $7.88-7.49(7 \mathrm{H}, \mathrm{m}, \mathrm{Ar}-\mathrm{H})$.

2d Brown powder in $70 \%$ yield ,m.p. $>300^{\circ} \mathrm{C}$; anal calc for $\mathrm{C}_{28} \mathrm{H}_{20} \mathrm{~N}_{2} \mathrm{O}_{4}(448): \mathrm{C}, 75.00 ; \mathrm{H}, 4.46$ $\mathrm{N}, 6.25 ;$ Found:C,74.98; $\mathrm{H}, 4.44 ; \mathrm{N}, 6.21$. IR (cm-1):1752.30(CO, Lactone) ,1616.6-1637.1 (C=N) $1364.90\left(\mathrm{CH}_{3}\right)$. $\delta \mathrm{H}: 6.88$ 6.84(2H, s, 2x CH-Coumarins), 7.507(1H, s, N=CH), $7.504(1 \mathrm{H}, \mathrm{s}, \mathrm{N}=\mathrm{CH}), 7.49-7.19(10 \mathrm{H}, \mathrm{m}, \mathrm{Ar}-\mathrm{H}), 2.49-1.45(6 \mathrm{H}, \mathrm{s}$, $\left.2 \times \mathrm{CH}_{3}\right)$.

\section{Synthesis of (2R)-2-(4-methoxyphenyl)-3-(4-methyl-2-oxo-2H-chromen-6-yl)-2,3- dihydro-1,3-oxazepine-4,7-dione3}

\section{A- Conventional method}

A mixture of $2 \mathrm{c}(0.01 \mathrm{~mol} ; 2.93 \mathrm{gm})$ and anhydrous maleic anhydride $(0.01 \mathrm{~mol})$ was heated under reflux in dry benzene on water bath for 2 hours, the solid was collected after concentration and recrystallized from EtOH/petroleum ether.

\section{B- Microwave method}

A mixture of $2 \mathrm{c}(0.01 \mathrm{~mol} ; 2.93 \mathrm{gm})$ and anhydrous maleic anhydride $(0.01 \mathrm{~mol})$ was added in Pyrex flask. The mixture was irradiated in an ultrasonic cleaner under solvent free for 7 minutes to complete the reaction (Monitored by TCL), cooling to room temperature. The reaction mixture was quenched with $20 \mathrm{~cm}^{3} \mathrm{H}_{2} \mathrm{O}$. The pure product that separate, filtered off and recrystallized from EtOH/petroleum ether.

3 Dark green powder in $60 \%$ yield, $m$.p. $244^{\circ} \mathrm{C}$; anal calc for $\mathrm{C}_{23} \mathrm{H}_{17} \mathrm{NO}_{6}(403) \mathrm{C}$ 68.49; H,4.22;N,3.47;Found:C,68.47; H,4.20;N,3.44. MS(m/z,\%)391(5.90\%). IR (cm-1): 1750.00(CO, lactone), 1663.34(C=O). $\delta \mathrm{H}: 7.498-7.185(7 \mathrm{H}, \mathrm{m}, \mathrm{Ar}-\mathrm{H}), 6.891(2 \mathrm{H}, \mathrm{d}, \mathrm{CH}=\mathrm{CH}), 6.268(1 \mathrm{H}, \mathrm{s}, \mathrm{C}=\mathrm{CH}), 3.916\left(3 \mathrm{H}, \mathrm{s}, \mathrm{OCH}_{3}\right), 6.920(1 \mathrm{H}$, $\mathrm{s}, \mathrm{N}-\mathrm{CH}-\mathrm{O}), 1.234\left(3 \mathrm{H}, \mathrm{s}, \mathrm{CH}_{3}\right)$

\section{Synthesis of 4-(4-methoxyphenyl)-9-methyl-7-oxo-2-thioxo-2,7-dihydropyrido[2,3-g] quinazoline $-6(1 \mathrm{H})$-carbothioamide 5}

A mixture of $1(0.01 \mathrm{~mol} ; 1.75 \mathrm{gm})$ and thiourea $(0.01 \mathrm{~mol} ; 0.76 \mathrm{gm})$, 4-methoxybenzaldehyde $(0.01 \mathrm{~mol} ; 1.36 \mathrm{gm})$ was added and the reaction mixture was heated under microwave irradiation conditions for 7 minutes in the presence of few drops of acetic acid as a catalyst. The solid separate was collected, recrystallized from acetone/ethanol (1:1) to give 5

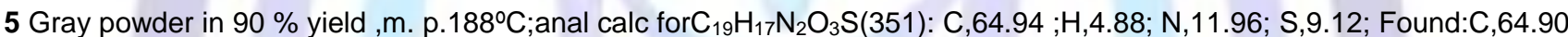
;H,4.83;N,11.90; S,11.86. IR (cm-1):1595.80 (C=N), $1250.54(\mathrm{C}=\mathrm{S}), 2685.39(\mathrm{SH}), 3156.24(\mathrm{NH}), 3265.44,3368.87$ $\left(\mathrm{NH}_{2}\right) . \mathrm{MS}(\mathrm{m} / \mathrm{z}, \%) 351(0.62 \%), 352(0.44 \%) \mathrm{M}^{+1}, 353(0.34 \%) \mathrm{M}^{+2}, 354(2.17 \%) \mathrm{M}^{+3}$.

\section{Synthesis of 4-methyl-6-((5-(4-methyl-2-oxo-2H-chromen-6-yl)-2-thioxo-1,3,5- trizinan-1-yl)methyl amino)-2H-chromen 2-one 6}

A mixture of $1(0.02 \mathrm{~mol} ; 3.5 \mathrm{gm})$, thiourea $(0.01 \mathrm{~mol} ; 0.57 \mathrm{gm})$ and formaldehyde $(0.03 \mathrm{~mol})$ in absolute ethanol $(50 \mathrm{ml})$ was refluxed for $6 \mathrm{hrs}$. The solid was collected and recrystallized from acetone/ethanol to give 6

6 Gray powder in $75 \%$ yield, m .p $31{ }^{\circ} \mathrm{o}$; ; anal calc for $\mathrm{C}_{24} \mathrm{H}_{22} \mathrm{~N}_{4} \mathrm{O}_{4} \mathrm{~S}(462)$ : C, $62.34 ; \mathrm{H}, 4.76 ; \mathrm{N}, 12.12 ; \mathrm{S}, 9.63 ; \mathrm{Found}$ : $\mathrm{C}, 64.32 ; \mathrm{H}, 4.75 ; \mathrm{N}, 12.10 ; \mathrm{S}, 6.90$. IR ( $\left.\mathrm{cm}^{-1}\right): 1750.00$ (CO, lactone), 1203.74(C=S), 2652.33(SH), $3290.39(\mathrm{NH}) .8 \mathrm{H}: 9.075($ $\left.\mathrm{t}, 1 \mathrm{H}, \mathrm{NHCH}_{2}\right), 9.075\left(\mathrm{t}, 1 \mathrm{H}, \mathrm{NHCH}_{2} \mathrm{~N}\right), 9.696\left(\mathrm{~b}, 1 \mathrm{H}, \mathrm{CSNHCH}_{2}\right), 5.36\left(\mathrm{dd}, 2 \mathrm{H}, \mathrm{CSNHCH} \underline{\mathrm{N}}_{2}\right), 5.45\left(\mathrm{dd}, 2 \mathrm{H}, \mathrm{NH} \underline{\mathrm{CH}}_{2} \mathrm{~N}\right), 4.92$ $\left(\mathrm{s}, 2 \mathrm{H}, \mathrm{NCH}_{2} \mathrm{~N}\right), 1.23-1.45\left(\mathrm{~s}, 6 \mathrm{H}, 2 \times \mathrm{CH}_{3}\right.$-Coumarin), $683-7.056(\mathrm{~m}, 6 \mathrm{H}, \mathrm{Ar}-\mathrm{H}), 6.18$.

\section{Synthesis of8-(4-methoxyphenyl)-1-methyl-9,10,11,12-tetrahydropyrano[3,2- a]phenan thridin-3-one 7.}

To ethanolic solution of $1(0.01 \mathrm{~mol} ; 1.75 \mathrm{gm})$ and anisaldehyde $(0.01 \mathrm{~mol})$, cyclohexanone $(0.01 \mathrm{~mol})$ was added .The reaction mixture was heated under reflux for $6 \mathrm{hrs}$. in the presence of traces of iodine as a catalyst. The solid that separate was filtered off and recrystallized from ethanol/water (1:1) to give 7.

7 Brown powder in $75 \%$ yield, $m$.p. over $300^{\circ} \mathrm{C}$; anal calc for $\mathrm{C}_{24} \mathrm{H}_{23} \mathrm{NO}_{3}(371): \mathrm{C}, 77.61 ; \mathrm{H}, 5.70 ; \mathrm{N}, 3.73 ;$ Found:C,77.44; $\mathrm{H}, 5.65$; N,3.70. IR $\left(\mathrm{cm}^{-1}\right): 1724.01\left(\mathrm{CO}\right.$, lactone), $1606.55(\mathrm{C}=\mathrm{N}) \cdot 1377.7\left(\mathrm{CH}_{3}\right) . \delta \mathrm{H}: 1.45\left(\mathrm{~s}, 3 \mathrm{H}, \mathrm{CH}_{3}-\mathrm{Coumarin}\right), 5.45(\mathrm{~s}, 1 \mathrm{H}-$ Comarin), 2.75-3.20(m,8H,4xCH 2$), 6.85-7.95(\mathrm{~m}, 6 \mathrm{H}, \mathrm{Ar}-\mathrm{H}), 3.77\left(\mathrm{~s}, 3 \mathrm{H}, \mathrm{OCH}_{3}\right) \cdot \mathrm{MS}(\mathrm{m} / \mathrm{z} \%) 371(0.33 \%)$.

\section{Synthesis of ethyl 3-cyano-3-(4,7-dimethyl-2-oxo-4a,10a-dihydro-2H-pyrano[2,3g] quinolin -9-yl)propanoate 8}

To a mixture of $1(0.01$ mole; $1.75 \mathrm{gm})$ and ethyl acetoacetate $(0.01 \mathrm{~mol})$, ethyl cyano acetate $(0.01 \mathrm{~mol})$ was added. The reaction mixture was fused for $6 \mathrm{hrs}$. The precipitate was collected and recrystallized from ethanol to give 8 .

8 Brown powder in $60 \%$ yield, m. p. $290 \stackrel{\circ}{\mathrm{C}}$; anal calc for $\mathrm{C}_{20} \mathrm{H}_{20} \mathrm{~N}_{2} \mathrm{O}_{4}(352): \mathrm{C}, 68.18 ; \mathrm{H}, 5.68$;N,7.95; Found: C,68.15; H,5.66; $\mathrm{N}$,7.92. IR $\left(\mathrm{cm}^{-1}\right): 1733.01\left(\mathrm{CO}\right.$, lactone), 1365.66 $\left(\mathrm{CH}_{3}\right), 2263.03(\mathrm{C} \equiv \mathrm{N}), 3180(\mathrm{NH}) . \quad \mathrm{MS}:(\mathrm{m} / \mathrm{z} \%) 336(4.52 \%)$ 
$\delta \mathrm{H}: 1.310\left(3 \mathrm{H}, \mathrm{t}, \quad \mathrm{CH}_{3}\right.$-ester), 4.29-4.35(2H ,q , $\mathrm{CH}_{2}$-ester), 2.03(3H,s, $\mathrm{CH}_{3}$-Coumarin), 6.875(1H, s, CH-Coumarin), 2.699(3H,s, $\mathrm{CH}_{3}$-pyridone), 7.648-7.016(4H, m, Ar-H) and 8.18(1 $\mathrm{H}, \mathrm{NH}-$ pyridine $)$.

\section{Synthesis of 2-chloro-N-(4-methyl-2-oxo-2H-chromen-6-yl)acetamide 9}

A mixture of $\mathbf{1}(0.01 \mathrm{~mole} ; 1.75 \mathrm{gm})$ and chloroacetylchloride $(0.01 \mathrm{~mol})$ in $(40 \mathrm{ml})$ methanol was refluxed for 4 hrs. The reaction mixture was cooled, poured onto ice, filtered off, dried, and recrystallized from ethanol/water (1:1) to give 9.

9 Gray powder in $60 \%$ yield, m. p. $200{ }^{\circ} \mathrm{C}$; anal calc for $\mathrm{C}_{12} \mathrm{H}_{10} \mathrm{ClNO}_{3}(251.5): \mathrm{C}, 57.26 ; \mathrm{H}, 3.98 ; \mathrm{N}, 5.57 ; \mathrm{Cl}, 14.12$;

Found:C,57.24; H,3.96; N,5.55; Cl,14.00. IR (cm-1):1628.4 (CO) amide, 1750.0(CO, lactone), 3297.6(NH). $\delta \mathrm{H}: 9.653(1 \mathrm{H}$, $\mathrm{s}, \mathrm{NH}), 6.887\left(1 \mathrm{H}, \mathrm{s}, \mathrm{CH}\right.$-Coumarin), 7.492-7.178(3H, m, Ar-H), 3.416(2H, s, $\left.\mathrm{COCH}_{2}\right)$ and 1.3(3H, s, $\mathrm{CH}_{3}-C_{-}$.

\section{Synthesis of 6-[(2-amino-1,3-oxazol-5-yl)amino]-4-methyl-2H-chromen-2-one 10 or 6-[(2- amino-1,3-thiazol-5-yl)amino]-4-methyl-2H-chromen-2-one 11.}

A mixture of $9(0.01 \mathrm{~mole} ; 2.52 \mathrm{gm})$ and urea or thiourea $(0.01 \mathrm{~mol})$ in $(30 \mathrm{ml})$ ethanol was refluxed for $6 \mathrm{hrs}$. The reaction mixture was cooled, poured onto ice $\mathrm{H}_{2} \mathrm{O}$, filtered off, dried, and recrystallized from ethanol to give $\mathbf{1 0}$ and 11.

10 Dark gray powder in $80 \%$ yield, m.p. $>300^{\circ} \mathrm{C}$; anal calc for $\mathrm{C}_{13} \mathrm{H}_{11} \mathrm{~N}_{3} \mathrm{O}_{3}(257)$ : C,60.70; $\mathrm{H}, 4.28 ; \mathrm{N}, 16.34$; Found:C,60.68; $\mathrm{H}, 4.25 ; \mathrm{N}, 16.31$. IR (cm-1): 1720.00(CO, lactone), 1366.77( $\left.\mathrm{CH}_{3}\right), 3405.32-3329.18(\mathrm{NH}, \mathrm{NH}), 1591.27$ $(\mathrm{C}=\mathrm{N}) . \delta \mathrm{H}: 1.054\left(3 \mathrm{H}, \mathrm{s}, \mathrm{CH}_{3}\right), 4.938\left(2 \mathrm{H}, \mathrm{s}, \mathrm{NH}_{2}\right), 9.696(1 \mathrm{H}, \mathrm{s}, \mathrm{NH}), 5.16(1 \mathrm{H}, \mathrm{s}, \mathrm{CH}-\mathrm{Coumarin}$ ring $), 5.9(1 \mathrm{H}, \mathrm{s}, \mathrm{CH}-$ Oxazole) and 7.561-7491(3H, m, Ar-H).

11 as dark gray powder in $70 \%$ yield,m.p. $300^{\circ} \mathrm{C}$; anal calc for $\mathrm{C}_{13} \mathrm{H}_{11} \mathrm{~N}_{3} \mathrm{O}_{2} \mathrm{~S}(273): \mathrm{C}, 57.14 ; \mathrm{H}, 4.02 ; \mathrm{N}, 15.38 ; \mathrm{S}, 11.72$; Found: C,57.12; $\mathrm{H}, 4.00 ; \mathrm{N}, 15.35 ; \mathrm{S}, 11.65$. IR (cm-1): 1752.40(CO,lactone) , 1367.00( $\left.\mathrm{CH}_{3}\right), 3345.2-3297.4\left(\mathrm{NHNH}_{2}\right), 1629.2$ $(\mathrm{C}=\mathrm{N}) . \delta \mathrm{H}: 1.240\left(3 \mathrm{H}, \mathrm{s}, \mathrm{CH}_{3}\right), 4.264\left(2 \mathrm{H}, \mathrm{s}, \mathrm{NH}_{2}\right), 9.671(1 \mathrm{H}, \mathrm{s}, \mathrm{NH}), 5.926(1 \mathrm{H}, \mathrm{s}, \mathrm{CH}-$ Coumarin ring $), 6.919(1 \mathrm{H}, \mathrm{s}, \mathrm{CH}-$ Thiazole ring) and 7.503-7.185(3H, m, Ar-H).

\section{Synthesis of N-(4-methyl-2-oxo-2H-chromen-6-yl) acetamide12}

A mixture of $1(0.01 \mathrm{~mol} ; 1.75 \mathrm{gm})$ and acetic anhydride $(0.01 \mathrm{~mol})$ in the presence of glacial acetic acid was refluxed for 2 hrs. The resulted solution was cooled to room -temp, poured ointo ice/cold water, the solid that separate was filtered off and recrystallized from ethanol to give 12.

12 Gray powder in70 \% yield, m .p. $280 \stackrel{\circ}{\circ} \mathrm{C}$;anal calc for $\mathrm{C}_{12} \mathrm{H}_{11} \mathrm{NO}_{3} \quad(217): \mathrm{C}, 66.36 ; \quad \mathrm{H}, 5.07 ; \quad \mathrm{N}, 6.45$; Found:C,66.34; $\mathrm{H}, 5.00 ; \mathrm{N}, 6.44$. MS: (m/z \%) 217(2.17\%). IR $\left(\mathrm{cm}^{-1}\right)$ : $1668.0 \mathrm{C}=\mathrm{O}$ amid, $1752.0(\mathrm{CO}$, lactone $), 3151.2(\mathrm{NH})$. $\delta \mathrm{H}: 1.7\left(3 \mathrm{H}, \mathrm{s}, \mathrm{CH}_{3}\right.$-Coumarin), 1.905(3H, s, $\left.\mathrm{COCH}_{3}\right), 9.707(1 \mathrm{H}, \mathrm{s}, \mathrm{NH}), 7.667-6.661(4 \mathrm{H}, \mathrm{m}, \mathrm{Ar}-\mathrm{H}$ and CH-Coumarin) .

\section{Synthesis of (2E)-3-(4-bromophenyl)-N-(4-methyl-2-oxo-2H-chromen-6-yl)prop-2- enamide 13}

A mixture of $12(0.01 \mathrm{~mol} ; 2.17 \mathrm{gm})$ and 4-bromobenzaldehyde $(0.01 \mathrm{~mol})$ was reacted under microwave irradiation and solvent free conditions for 3 minutes. The solid product was recrystallized from ethanol/petroleum ether (1:1) to give $\mathbf{1 3}$

13 Brown powder, in $60 \%$ yield, m.p. $300 \mathrm{C}^{0}$; anal calc for $\mathrm{C}_{19} \mathrm{H}_{14} \mathrm{BrNO}_{3}(384)$ : C,59.38; $\mathrm{H}, 3.65 ; \mathrm{N}, 3.65 \mathrm{Br}, 9.11$; Found:C,59.36; $\mathrm{H}, 3.63 ; \mathrm{N}, 3.62 ; \mathrm{Br}, 9.00$. IR (cm-1)1750.6 (CO, lactone), $1369.50\left(\mathrm{CH}_{3}\right), 3287.49(\mathrm{NH}), 1649.69(\mathrm{C}=\mathrm{O})$ amide. $\delta \mathrm{H}: 1.977\left(3 \mathrm{H}, \mathrm{s}, \mathrm{CH}_{3}\right.$-Coumarin), 8.928(1H,s, NH), 7.788-7.555(7H, m, Ar-H) 5.922(1H, s, CH-Coumarin) ,6.868$6.840(2 \mathrm{H}, \mathrm{d}, \mathrm{CH}=\mathrm{CH})$.

\section{Synthesis of6-(5-(4-bromophenyl)-4,5-dihydro-1H-pyrazol-3-ylamino)-4-methyl-2H- chromen-2-one 14}

To ethanolic solution of $13(0.01 \mathrm{~mol})$ hydrazine hydrate $(0.01 \mathrm{~mole})$ was added . The reaction mixture was heated under reflux for 6 hrs. The reaction mixture was cooled to room-temp; Poured onto ice/water, the solid that separate was collected, filtered off and recrystallized from ethanol to give 14.

14 White crystals, in $75 \%$ yield ,m.p. $185^{\circ} \mathrm{C}$; anal calc $\mathrm{C}_{19} \mathrm{H}_{16} \mathrm{BrN}_{3} \mathrm{O}_{2}(397) ; \mathrm{C}, 57.30 ; \mathrm{H}, 4.05 ; \mathrm{N}, 10.55 ; \mathrm{Br}, 20.06 ; \mathrm{Found}$ : $\mathrm{C}, 57.22 ; \mathrm{H}, 4.00 ; \mathrm{N}, 10.51 ; \mathrm{Br}, 20.00$. IR (cm-1) 1750.6(CO, lactone), $1369.50\left(\mathrm{CH}_{3}\right), 3297.2(\mathrm{NH}) . \delta \mathrm{H}: 1.234\left(3 \mathrm{H}, \mathrm{s}, \mathrm{CH}{ }_{3}\right.$

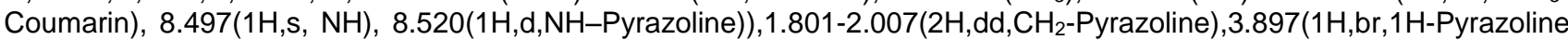
) 7.023-7.974(7H, m, Ar-H) 6.950(1H,s, CH-Coumarin) .

\section{ANTI-INFLAMMATORY SCREENING}

Animals: A total number of 42 adult female Swiss albino rats $(140-190 \mathrm{~g})$ purchased from the breeding unit of the Egyptian Organization for Biological products and Vaccines (Helwan, Egypt) were used in this study. The animals were housed in steel mesh cages (3/cage) and maintained on a commercial pellet diet (Egyptian Company of Oils and Soaps) for one week before starting the experiment as an acclimatization period.

\section{Preparation and administration of chemical compounds used}


Compounds 1, 2a, 11and12 were synthesized, as previously described. A weight of $50 \mathrm{mg}$ was dissolved in $5 \mathrm{ml} 10 \%$ DMSO to prepare stock solutions $(10 \mathrm{mg} / \mathrm{ml})$ from these compounds. The solutions were prepared weekly and preserved in a well stopper bottle at $4^{\circ} \mathrm{C}$. The synthesized solutions were orally administrated to the animals at a dose level of $10 \mathrm{mg} / \mathrm{kg}$ body weight according to [31].

\section{Induction of Inflammation}

Induction of inflammation in rats was carried out mainly according to [36]. Inflammation was induced by injecting $0.05 \mathrm{ml}$ of $1 \%$ carrageenan (freshly prepared in saline) subcutaneously into the sub plantar region of the left hind paw.

\section{Design of the work}

All rats were assorted into 3 reference groups and 4 treated groups according to the following scheme.

Group 1: Normal control (Con):

This group comprised 6 normal rats fed a commercial pellet diet and left intact without any treatment.

Group 2: Carrageenan (Carg):

This group involved 6 rats injected with $0.05 \mathrm{ml}$ of $1 \%$ carrageenan one hour after oral administration of saline serving as a reference group for the treated groups.

Group 3: Vehicle group (Carg +DMSO):

This group comprised 6 rats received 10\% DMSO one hour before carrageenan injection serving as a vehicle group.

Groups 4- 7:

One hour prior to carageenan injection, the group's 4-7 received a daily oral dose of $10 \mathrm{mg} / \mathrm{kg}$ body weight of compounds 1, 2a, 11 and 12 , respectively.

Anti-inflammatory activity was evaluated by measuring carrageenan induced rat paw edema before (zero time) and after carrageenan injection of time intervals $1^{\text {st }}, 2^{\text {nd }}, 3^{\text {rd }}$ and $4^{\text {th }}$ hour. Increase in paw thickness was measured as the difference in paw thickness at "0 hour" and paw thickness at respective hours. The percentage of inhibition was calculated from the formula [37]:

$\%$ Inhibition $=[(\mathrm{D} 0-\mathrm{Dt}) / \mathrm{D} 0] \times 100$

Where D0 = Average paw inflammation of Carg. Group at a given time.

$\mathrm{Dt}=$ Average paw inflammation of treated group at a given time.

At the end of the treatment period blood samples were taken from the retro-orbital venous plexus under light ether anesthesia. Serum was prepared by centrifuging blood samples at $4000 \mathrm{rpm}$ for $5 \mathrm{~min}$. Serum samples were aliquoted and stored at $-20^{\circ} \mathrm{C}$ until analysis, Non hemolyzed sera were analyzed for pro-inflammatory cytokines, IL-6 and TNF- $\alpha$ and anti-inflammatory cytokine, IL-10using a commercial assay kit (R \& D Systems, USA).

\section{Statistical analysis:}

The data were presented as mean \pm SD. One way analysis of variance (ANOVA) followed by post hoc least significant difference analysis (LSD) was performed using the statistical package for social science (SPSS) version 16 to compare all the treated groups. The value of $p \leq 0.05$ was considered statistically significant.

\section{RESULTS AND DISCUSSION}

\section{Chemistry}

In this investigation, a series of new pyrazole, oxazole, thiazole, pyridine, pyrimidine and 1,3,oxazepine derivatives incoporating coumarin nucleus were designed, synthesized (Schemes 1-5), and biologically evaluated for their in vivo anti-inflammatory activity[13-17]. Thus, compound 1 condenses easily with aromatic aldehydes namely, cinnamaldehyde, 3-nitrobenzaldehyd, 4-methoxylbenzaldehyde and terephthalaldehyde in absolute ethanol in the presence of few drops of acetic acid under reflux afforded Schiff's bases $\mathbf{2 a - d}$ in excellent yield [18]. The chemical structures of 2a-d were elucidated on the basis of elemental analysis and spectral data. The ${ }^{1} \mathrm{H}$ - NMR spectra indicated the appearance of a singlet signal for $\mathrm{CH}=\mathrm{N}$ function and disappearance of the signal assigned to $\mathrm{NH}_{2}$ group. The structure of $2 \mathrm{a}$ also was supported by its mass spectrum, which revealed a molecular ion peak at $\mathrm{m} / \mathrm{z} 289\left(0.45 \% \mathrm{M}^{+}\right)$corresponding to the molecular formula CHON. Condensation of 6-(4-methoxyphenylimino)methyl)-4-methyl-2H-chromen-2-one 2c with anhydride namely, (maleic anhydride), under conventional , microwave irradiation and solvent free conditions afforded the corresponding cycloaddition product (Z)-2-(4-methoxyphenyl)-3-(4-methyl-2-oxo-2H-chromen-6-yl)-2,3-dihydro-1,3oxazepine-4,7-dione 3 based on elemental analysis and spectroscopy (scheme1) $[19,20]$. ${ }^{1} \mathrm{H}$ - NMR spectrum of 3 exhibited signals at $\delta 6.891(2 \mathrm{H}, \mathrm{d}, \mathrm{CH}=\mathrm{CH}), 6.268(1 \mathrm{H}, \mathrm{s}, \mathrm{C}=\mathrm{CH}), 3.916\left(3 \mathrm{H}, \mathrm{s}, \mathrm{OCH}_{3}\right)$ and $6.920(1 \mathrm{H}, \mathrm{s}, \mathrm{N}-\mathrm{CH}-\mathrm{O})$ functions and disappearance of signal assigned to $\mathrm{CH}=\mathrm{N}$ function group. The mass spectrum of $\mathbf{3}$ showed a molecular ion peak at $\mathrm{m} / \mathrm{z} 391\left(5.90 \% \mathrm{M}^{+}\right)$. 


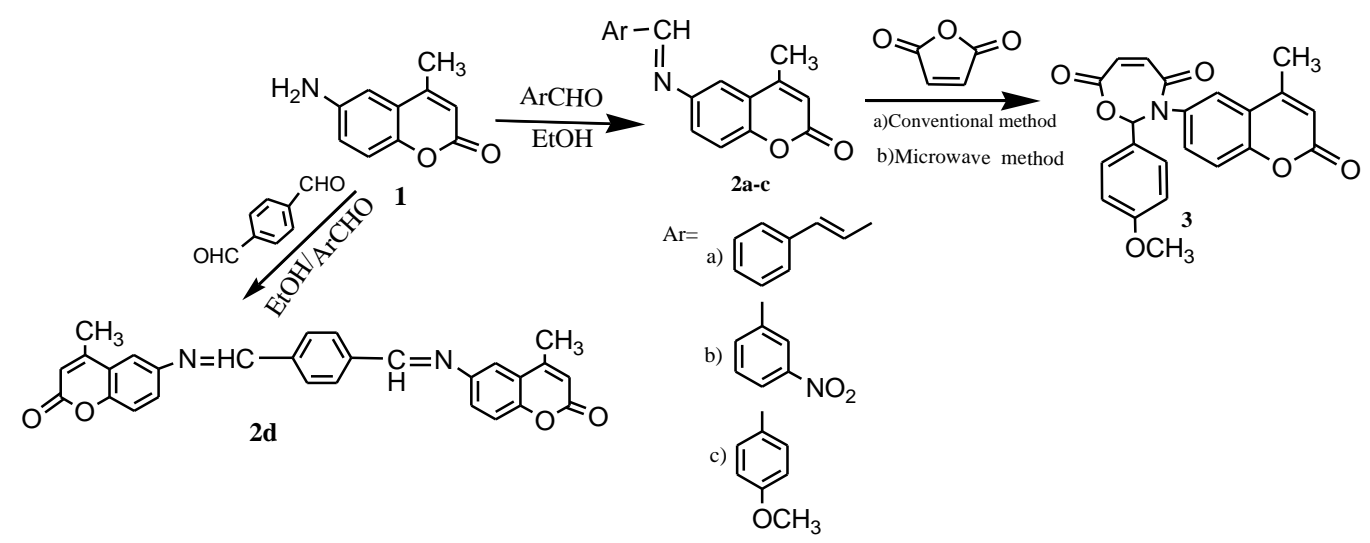

Scheme 1

On the other hand, the reactivity of compound 1 was investigated by condensation with (thiourea and 4methoxybenzaldehyde) compound 4 under microwave irradiation for seven minutes in the presence of acetic acid afforded the corresponding, 7-amino-4-(4-methoxyphenyl)-5-methyl-3,4-dihydrochromeno[2,3-d]pyrimidine-2-thione 5 (scheme 2) [21].<smiles>Cc1cc(=O)oc2ccc(N)cc12</smiles>

1<smiles>NC(=S)N=CBr</smiles>

4

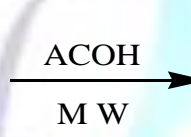

M W<smiles>CC1=C2C(=NC(=S)NC2Br)Oc2ccc(N)cc21</smiles>

5 $\mathrm{Ar}=\mathrm{C}_{6} \mathrm{H}_{4} \cdot \mathrm{OCH}_{3}(4)$

Scheme 2

The IR spectrum of 5 showed absorption bands at $1595.80 \mathrm{C}=\mathrm{N}, 1250.54 \mathrm{C}=\mathrm{S}, 2685.39 \mathrm{SH}, 3156.24 \mathrm{NH}$ and $3368.87-$ $3265.44 \mathrm{~cm}^{-1} \mathrm{NH}_{2}$ and indicated the disappearance of $\delta$-lactone. Its Mass spectrum showed molecular ion peak at $\mathrm{m} / \mathrm{z}$ $351\left[\mathrm{M}^{+}\right](0.62 \%)$.

The reaction takes place via the following mechanism:

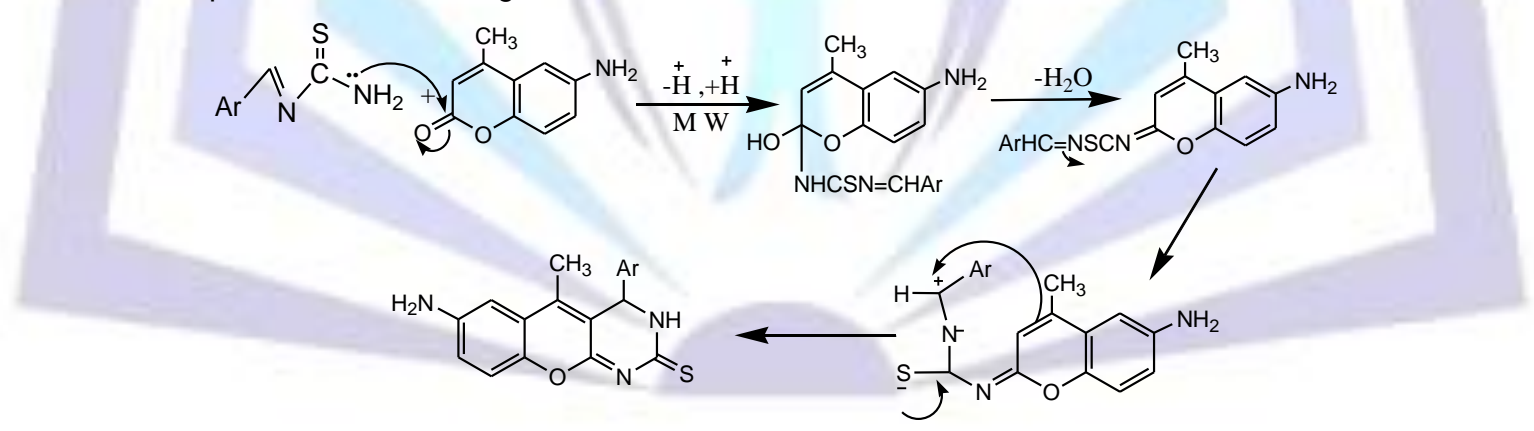

Furthermore, compound 1 was condensed with thiourea and formaldehyde in 2:1:3 $\mathrm{M}$ ratios in absolute ethanol and few drops of acetic acid under reflux to afford the corresponding ,4-methyl-6-(5-(4-methyl-2-oxo-2H-chromen-6-yl)-2-thioxo1,3,5-trizinan-1-yl) methylamino )-2H-chromen-2-one 6 [22]. IR spectrum of 6 revealed the absence of $\mathrm{NH}_{2}$ group and presence of absorption bands at $1750.0 \delta$-lactone, $1203.74 \mathrm{C}=\mathrm{S}, 2652.33 \mathrm{SH}$ and $3290.39 \mathrm{~cm}^{-1} \mathrm{NH}$. Its ${ }^{1} \mathrm{H}-\mathrm{NMR}$ spectrum indicated the presence of signals at $\left.\delta 9.075\left(\mathrm{t}, 1 \mathrm{H}, \mathrm{NHCH}_{2} \mathrm{~N}\right), 9.696\left(\mathrm{~b}, 1 \mathrm{H}, \mathrm{CSNHCH}_{2}\right), 5.36(\mathrm{dd}, 2 \mathrm{H}, \mathrm{CSNH} \underline{\underline{C H}})_{2}\right)$, $5.45\left(\mathrm{dd}, 2 \mathrm{H}, \mathrm{NH}_{\underline{\mathrm{CH}}} 2 \mathrm{~N}\right), 4.92(\mathrm{~s}, 2 \mathrm{H}, \mathrm{CH} 2)$ and absence of $\mathrm{NH}_{2}$ protons. 
<smiles>Cc1cc(=[O+][C-]C=O)oc2ccc(N)cc12</smiles>

$1 \quad$ Scheme 3<smiles>Cc1cc(=O)oc2ccc(NCN3CN(c4ccc5oc(=O)cc(C)c5c4)CNC3=S)cc12</smiles>

The reaction takes place according to the following mechanism:
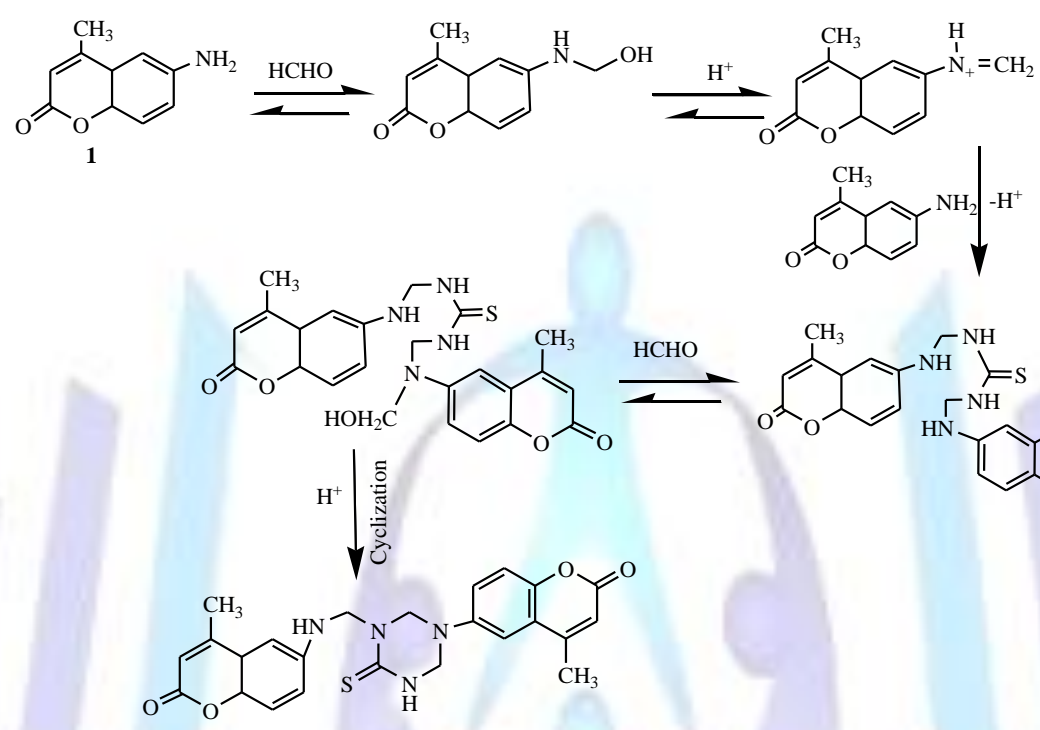<smiles>CC1=CC(=O)OC2C=CC(NCNC(=S)NCNc3ccc4oc(=O)cc(C)c4c3)=CC12</smiles>

In addition to, compound 1 was easily converted into 8-(4-methoxyphenyl)-1-methyl-9, 10, 11, 12-tetrahydropyrano [3, 2-a] phenanthridin-3-one 7 upon treatment with cyclohexanone and anisaldehyde in the presence of iodine as a catalyst under reflux for 6 hrs. [23-25] (Scheme 4). The features of this procedure are mild reaction conditions, good to high yields, and operational simplicity. IR spectrum of 7 showed absorption bands at $1606.55 \mathrm{~cm}^{-1}$ for $\mathrm{C}=\mathrm{N}$ and the absence of $\mathrm{NH}_{2} \mathrm{group}_{\text {. }}$ Its mass spectrum showed ion peak at $\mathrm{m} / \mathrm{z}, 371\left[\mathrm{M}^{+}\right](0.33 \%)$.

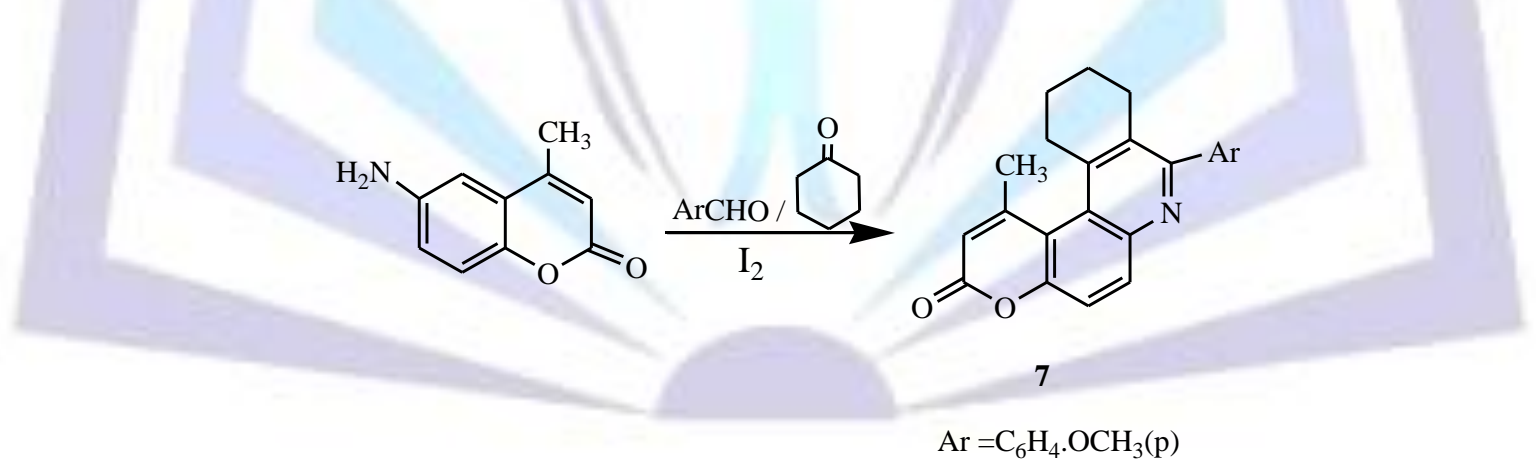

Scheme 4

The reaction takes place via mechanism 
$\mathrm{ArCHO}$<smiles>Cc1cc(=O)oc2ccc(N)cc12</smiles>

Fusion of 1 with ethyl acetoacetate and ethyl cyanoacetate afforded the corresponding (E)-ethyl 2-cyano-2-(4,7dimethyl-2-oxo-2H-pyrano[2,3-g]quinolin-9(6H)-ylidene)acetate 8[26] .IR spectrum of 8 showed absorption bands at $2263.03,3180.54 \mathrm{~cm}^{-1}$ attributable to $\mathrm{C} \equiv \mathrm{N}$ and $\mathrm{NH}$ functional groups. The molecular structure of compound 8 also was established by ${ }^{1} \mathrm{H}$ NMR spectrum which exhibited the presence of triplet at $\delta 1.310$ and a quartet at $\delta 4.29$ assigned for ethyl ester moiety and a singlet signal at $\delta 8.18$ for $\mathrm{NH}$-pyridine. The mass spectrum of $\mathbf{8}$ showed molecular ion peak at $\mathrm{m} / \mathrm{z}(336)(4.52 \%)$.

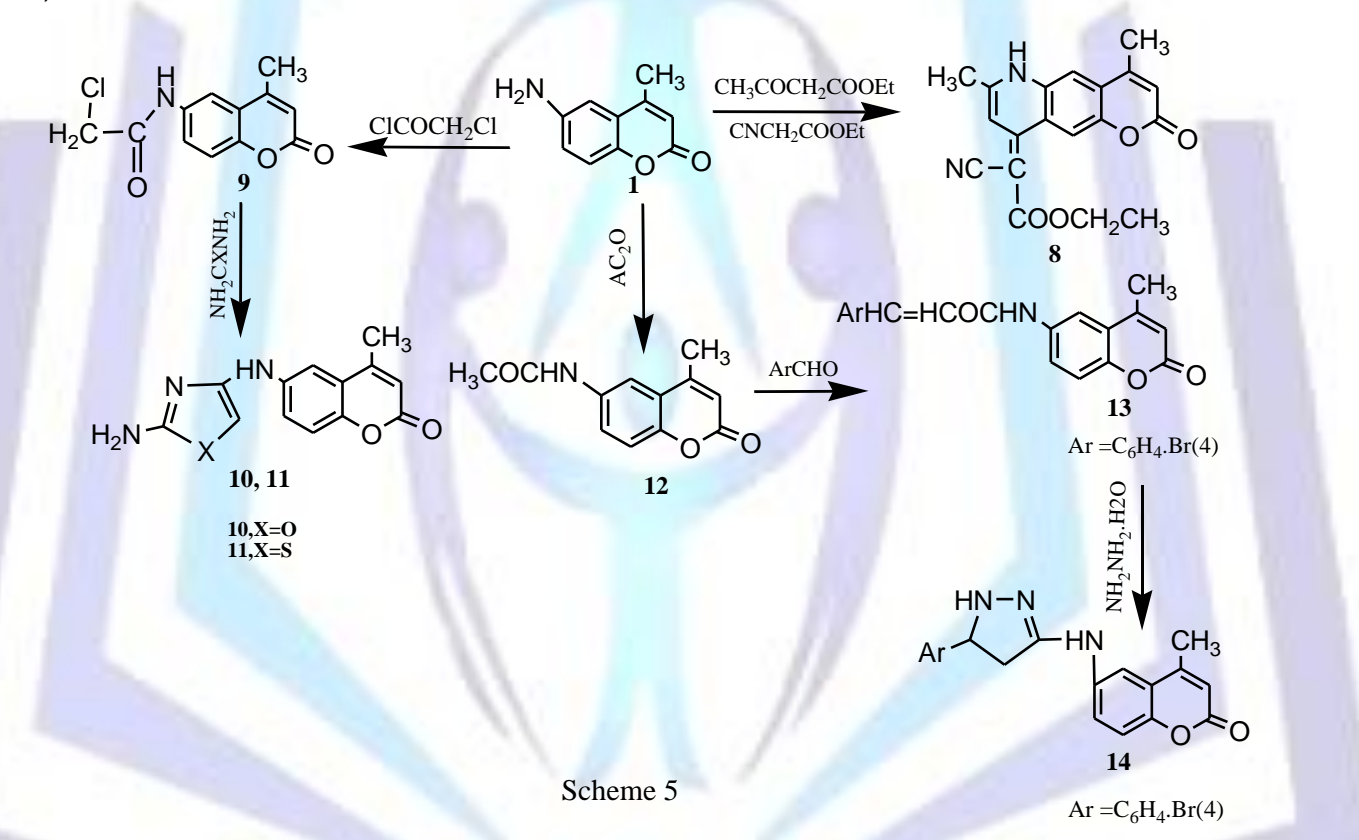

On the other hand, compound 1 was reacted with chloracetyl chloride in methanol under reflux for 6 hours to afford 2 chloro-N-(4-methyl-2-oxo-2H-chromen-6-yl)acetamide 9 in which amino group converted into amide group[27]. IR spectrum of 9 indicated the absence of amino group and presence of absorption bands at $3297.6 \mathrm{NH}$ and $161628.4 \mathrm{~cm}^{-1}$ CONH Its ${ }^{1} \mathrm{H}$ - NMR spectrum showed singlet signals at $\delta 9.653 \mathrm{NH}$ proton and $3.416\left(\mathrm{COCH}_{2}\right)$ protons.

The structure of 9 was confirmed chemically upon reaction with urea and/or thiourea in boiling ethanol afforded the corresponding 6-[(2-amino-1,3-oxazol-4-yl)amino]-4-methyl-2H-chromen-2-one $\mathbf{1 0}$ and 6-[(2-amino-1,3-thiazol-4-yl) amino]-4-methyl-2H-chromen-2-one 11, respectively[28]. The infrared spectrum in complete agreement with this structure that revealed absorption bands at 3405.32-3329.18and $1591.27 \mathrm{~cm}^{-1}$ for $\mathrm{NH}, \mathrm{NH}_{2}$ and $\mathrm{C}=\mathrm{N}$ functional groups. The ${ }^{1} \mathrm{H}-$ NMR of compound 10 showed signals at $\delta 4.938 \mathrm{NH}_{2}, 9.696 \mathrm{NH}$ and $5.9 \mathrm{CH}$-oxazole. IR spectrum of 11 showed absorption bands at 3345.2-3297.4and $1629.2 \mathrm{~cm}^{-1}$ for $\mathrm{NH}, \mathrm{NH}_{2}$ and $\mathrm{C}=\mathrm{N}$. Its ${ }^{1} \mathrm{H}-\mathrm{NMR}$ showed signals at $\delta 4.264 \mathrm{NH}_{2}$, $9.671 \mathrm{NH}$, and $6.919 \mathrm{CH}$-thiazole.

Furthermore, treatment of $\mathbf{1}$ with acetic anhydride in the presence of glacial acetic acid afforded the corresponding $\mathrm{N}$ (4-methyl-2-oxo-2H-chromen-6-yl)-acetamide 12 [29]. Its IR spectrum revealed the presence of absorption bands at $1668.0,3151.2 \mathrm{~cm}^{-1}$ attributed to $\mathrm{C}=\mathrm{O}, \mathrm{NH}$ and the absence of $\mathrm{NH}_{2}$ group. The ${ }^{1} \mathrm{H}-\mathrm{NMR}$ of 12 showed singlet signals at $\delta 1.905 \mathrm{COCH}_{3}$ and $9.707 \mathrm{NH}$. Its mass spectrum showed ion peak at $\mathrm{m} / \mathrm{z}(217)(2.17 \%)$. Also the structure of 12 was further confirmed chemically by its reaction with 4-bromobenzaldehyde for 3 minutes under microwave irradiation and solvent free condition to afford (2E)-3-(4-bromophenyl)-N-(4-methyl-2-oxo-2H-chromen-6-yl) prop-2-enamide 13[27]. Its ${ }^{1} \mathrm{H}-\mathrm{NMR}$ showed doublet signal at $\delta 7.788$ for olefinic group. 
Interaction of $\mathbf{1 3}$ with hydrazine hydrate in ethanol under reflux afforded hydrazine derivative 14 [28]. Its IR spectrum revealed the absence of $\mathrm{C}=\mathrm{O}$ chalcone absorption band. The ${ }^{1} \mathrm{H}-\mathrm{NMR}$ of 14 showed signals at $\delta 2.0-1.8 \mathrm{CH}_{2}-\mathrm{pyrazoline}$ 4.0, 7.0 for $2 \mathrm{NH}$ and $3.9 \mathrm{CH}$-pyrazoline .

\section{ANTI-INFLAMMATORY ACTIVITY}

In vivo anti-inflammatory activity was evaluated for the newly synthesized compounds (1, 2a, 11 and 12$)$ using the carrageenan-induced rat paw edema protocol. The paw edema volume was evaluated 1, 2, 3and 4hrs after the induction of inflammation. The development of edema in the rat paw after injection of carrageenan is biphasic, the initial phase of inflammation $(0-2 \mathrm{hrs})$ has been attributed to the release of histamine, 5 -hydroxytryptamineand kinins, followed by a late phase $(2.5$ - 6hrs) mainly sustained by prostaglandin (PG) release and more recently have been attributed to the induction of cyclooxygenase-2 (COX-2) in the tissue [29]. Local neutrophil infiltration and activation also contribute to this inflammatory response by producing, among other mediators, oxygen-derived free radicals such as superoxide anion $\left(\mathrm{O}_{2}{ }^{-}\right.$ ) and hydroxyl radicals [30,31].

Data listed in Table 1 and figures 1 and 2 indicate that the newly synthesized compounds significantly $(p<0.01)$ reduce the rat paw edema volume during the four hours after administration of the carrageenan, compared to carrageenan group. Compounds 1, 2a and 12 exhibited the maximum inhibition of edema after $1 \mathrm{hr}$ from the time of carrageenan administration, while compound 11 reached the maximum inhibition of edema after $2 \mathrm{hrs}$ and the percentage of inhibition is decreased in all the tested compounds after $4 \mathrm{hrs}$ from the time of administration.

Table (1): The paw thickness $(\mathrm{mm})$ in the different studied groups expressed as Mean \pm SD.

\begin{tabular}{|c|c|c|c|c|c|}
\hline Groups & Zero & $1^{\text {st }} \mathrm{hr}$ & $2^{\text {nd }} \mathrm{hr}$ & $3^{\text {ra }} \mathrm{hr}$ & $4^{\text {th }} \mathrm{hr}$ \\
\hline Carg & $3.50 \pm 0.41$ & $4.36 \pm 0.51$ & $4.54 \pm 0.46$ & $4.69 \pm 0.41$ & $3.94 \pm 0.93$ \\
\hline Carg+DMSO & $2.84 \pm 0.19^{\mathrm{a}}$ & $3.02 \pm 0.11^{\mathrm{a}}$ & $3.58 \pm 0.60^{\mathrm{a}}$ & $4.19 \pm 0.43$ & $3.61 \pm 0.86$ \\
\hline 1 & $3.10 \pm 0.23^{\mathrm{a}}$ & $1.94 \pm 0.25^{\mathrm{a}, \mathrm{b}}$ & $2.04 \pm 0.05^{\mathrm{a}, \mathrm{b}}$ & $2.14 \pm 0.11^{\mathrm{a}, \mathrm{b}}$ & $2.28 \pm 0.35^{\mathrm{a}, \mathrm{b}}$ \\
\hline $2 \mathrm{a}$ & $2.75 \pm 0.25^{\mathrm{a}, \mathrm{c}}$ & $1.92 \pm 0.11^{\mathrm{a}, \mathrm{b}}$ & $2.42 \pm 0.58^{\mathrm{a}, \mathrm{b}}$ & $2.40 \pm 0.55^{\mathrm{a}, \mathrm{b}}$ & $2.58 \pm 0.54^{\mathrm{a}, \mathrm{b}}$ \\
\hline 11 & $3.12 \pm 0.23^{\mathrm{a}, \mathrm{d}}$ & $2.76 \pm 0.37^{\mathrm{a}, \mathrm{c}, \mathrm{d}}$ & $2.24 \pm 0.37^{\mathrm{a}, \mathrm{b}}$ & $2.32 \pm 0.43^{\mathrm{a}, \mathrm{b}}$ & $2.45 \pm 0.21^{\mathrm{a}, \mathrm{b}}$ \\
\hline 12 & $3 \pm 0.00^{\mathrm{a}}$ & $1.99 \pm 0.29^{\mathrm{a}, \mathrm{b}, \mathrm{e}}$ & $2.02 \pm 0.08^{\mathrm{a}, \mathrm{b}}$ & $2.35 \pm 0.36^{\mathrm{a}, \mathrm{b}}$ & $2.39 \pm 0.51^{\mathrm{a}, \mathrm{b}}$ \\
\hline
\end{tabular}

a: significance vsCarg group, b: significance vs carg +DMSO group, c: significance vs compound 1, d: significance vs compound 2a, e: significance vs compound 11 .

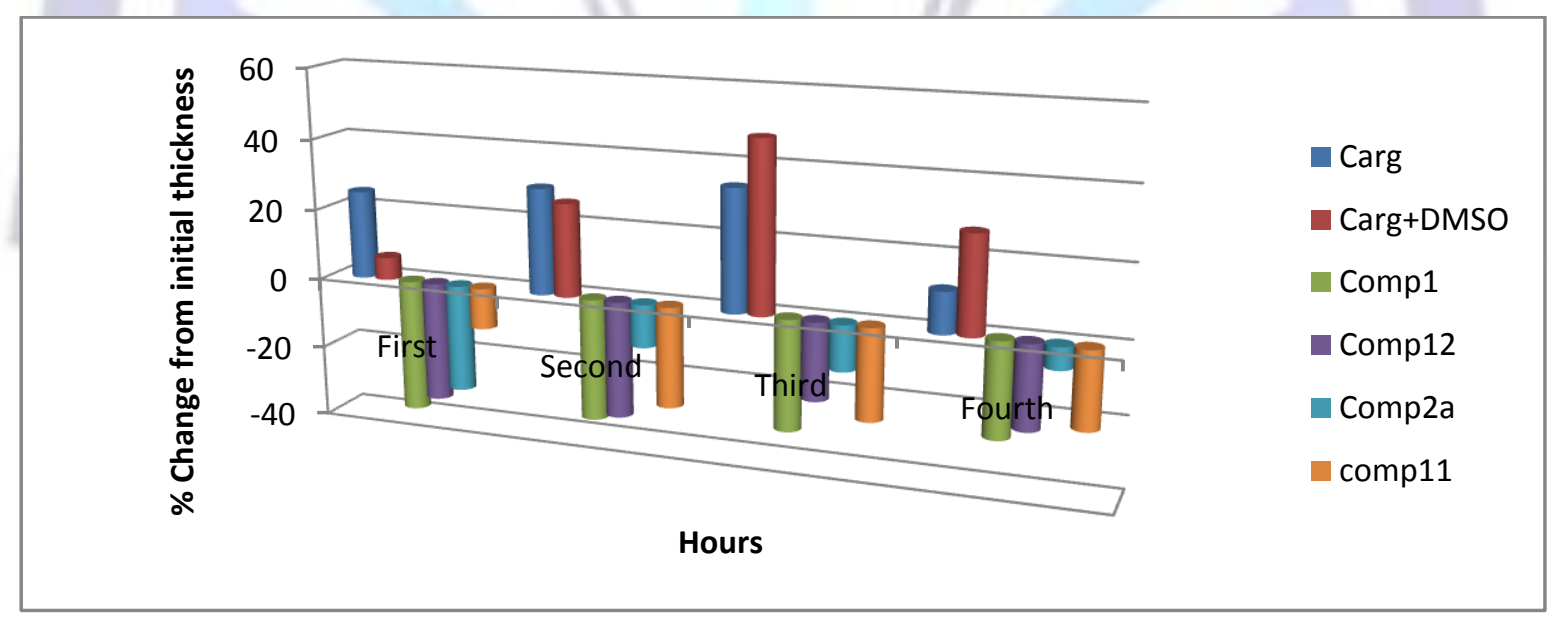

Figure (1): Effects of carrageenan and the tested coumarin derivatives on rats through four hours. 


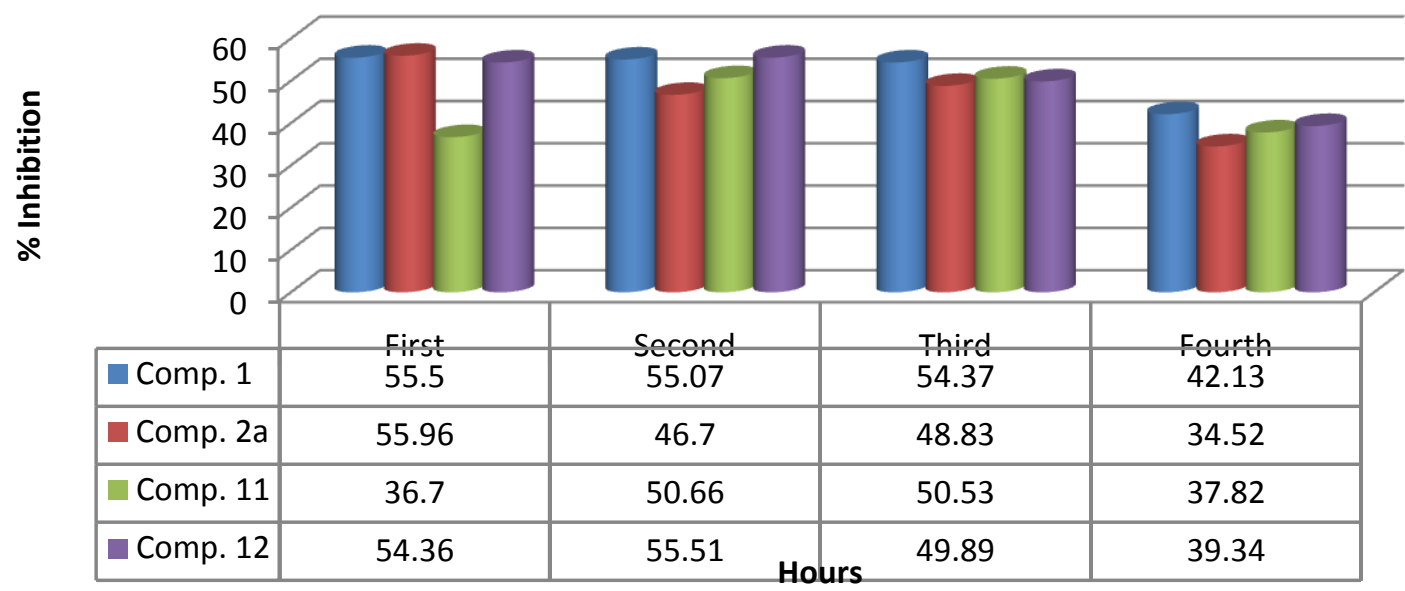

Figure (2): \% Inhibition of inflamed paw of rats treated with the tested coumarin derivatives through four hours.

These results are in line with [32,33] which reported that coumarin derivatives showed significant inhibition against carrageenan induced rat paw edema and inhibit prostaglandin biosynthesis. In addition, 6,7-dimethoxy-4-methylcoumarin inhibited PG-E2 production in LPS-stimulated RAW 264.7 cells by reducing the expression of COX-2 [34].

Local and/or systemic inflammation is associated with enhanced levels of the pro-inflammatory cytokines TNF- $\alpha$ and IL6[35].In the present study, serum levels of the pro-inflammatory cytokines IL-6 and TNF- $\alpha$ were significantly elevated ( $p<$ $0.01)$ in Carg and Carg +DMSO groups, whereas significant reduction $(p<0.01)$ was observed in the serum level of IL-10 as compared to control animals. Administration of the tested compounds, except compound $2 a$, reduced significantly serum IL-6 and induced serum IL-10, compared to Carg group. Moreover, serum TNF- $\alpha$ was significantly reduced in rats treated with compound 1. Although serum level of TNF- $\alpha$ was reduced in rats treated with compounds 11 and 12 , this reduction was statistically non-significant (table 2). These results agree with [36] which illustrated that couramin derivative were a potent inhibitor of IL-6 and TNF- $\alpha$ production in LPS-induced RAW 264.7 cells.

Multiple comparison analysis showed that compounds 11 and 12 were effective in reducing the pro-inflammatory IL-6, while compound 1 was effective in reducing the serum level of TNF- $\alpha$ and enhancing the anti-inflammatory IL- 10 .

Table (2): Effects of the tested coumarin derivatives and carrageenan treatment on the serum levels of IL-6, TNF-a and IL-10 (pg/ml) expressed as Mean \pm SD.

\begin{tabular}{|c|c|c|c|}
\hline Groups & IL-6 & TNF- $\alpha$ & IL-10 \\
\hline Con & $39.53 \pm 2.49$ & $42.33 \pm 3.98$ & $111.60 \pm 15.46$ \\
\hline Carg & $90.27 \pm 28.12^{\mathrm{a}}$ & $76.07 \pm 32.09^{\mathrm{a}}$ & $63.02 \pm 23.99^{\mathrm{a}}$ \\
\hline Carg+DMSO & $75.02 \pm 33.3^{\mathrm{a}}$ & $90.20 \pm 23.41^{\mathrm{a}}$ & $83.47 \pm 23.82^{\mathrm{a}}$ \\
\hline 1 & $61.98 \pm 25.26^{\mathrm{b}}$ & $51.53 \pm 6.8^{\mathrm{b}, \mathrm{c}}$ & $130.27 \pm 25.06^{\mathrm{b}, \mathrm{c}}$ \\
\hline $2 \mathrm{a}$ & $79.47 \pm 15.92^{\mathrm{a}}$ & $92 \pm 16.69^{\mathrm{a}, \mathrm{d}}$ & $81.97 \pm 19.42^{\mathrm{a}, \mathrm{d}}$ \\
\hline 11 & $53.4 \pm 13.4^{\mathrm{b}, \mathrm{e}}$ & $58.3 \pm 11.46^{\mathrm{c}, \mathrm{e}}$ & $109.07 \pm 6.02^{\mathrm{b}, \mathrm{c}, \mathrm{e}}$ \\
\hline 12 & $53.83 \pm 19.25^{\mathrm{b}, \mathrm{e}}$ & $61.8 \pm 9.05^{\mathrm{c}, \mathrm{e}}$ & $108.80 \pm 12.73^{\mathrm{b}, \mathrm{c}, \mathrm{e}}$ \\
\hline
\end{tabular}

a: significance vs Con, b: significance vs Carg, c: significance vs Carg +DMSO,d :significance vs compound 1, e: significance vs compound $2 \mathrm{a}$.

\section{CONCLUSION}

In the present study, a series of some new heterocyclic compounds (2-14) incorporating coumarin moiety was synthesized and assessed for their anti-inflammatory activity using the carrageenan-induced hind paw edema method. Some of the synthesized compounds exhibited significant anti-inflammatory activity, especially compounds 1, 2a and 12 exhibited the maximum inhibition of edema after $1 \mathrm{hr}$ from the time of carrageenan administration, while compound 11 reached the maximum inhibition of edema after $2 \mathrm{hrs}$ and the percentage of inhibition is decreased in all the tested compounds after 4 hrs from the time of administration.

\section{REFRENCES}

1. Nicplaou, K. C.; Pfeffercorn. J. A.; Roecker, A. J.; Cao, G. Q. ; Barluenga, S.; Mitchell, H. J. "Natural product-linked combinatorial libraries based on privileged structure I: general principles and solid phase synthesis of benzopyrans". J. Am. Chem., Soc. 2000, 9939-9953. 
2. Kazuo, M.; Kazuya, O.; Hironobu, H. Mukai, K.; Okabe, K.; Hosose, H. "Synthesis and stopped-flow investigation of antioxidant activity of tocopherols. Finding of new tocopherol derivatives having the highest antioxidant activity among phenolic antioxidant". J. Org. Chem., 1989, 54, 557-560 .

3. Kostova, I. "Synthetic and natural coumarins as cytotoxic Agents". Curr. Med. Chem., 2005, 5, 29-46.

4. Yourick, J. J.; Bronaugh, R. L. "Percutaneous absorption and mechanism of coumarin in human and rat skin". J. Appl. Toxicol., 1997, 17, 153-158

5. O'Kennedy, R.; Thornes, R. D. " Coumarins: Biology, Applications, and Mode of Action". John Wiley\&Sons, New York, 1997.

6. Nielson, B. E. "Heywood in the Biology and Chemistry of the Umbelliferae", Academic Press, London, 1971.

7. Murray, R. D. H.; Mendez, J.; Brown, S. A. "The Natural Coumarins, Occurrence, Chemistry and Biochemistry". John Wiely\&Sons, New York, 1982.

8. Yamazaki, H.; Tanaka, M.; Shimada, T. "Highly sensitive high-performance liquid chromatographic assay for coumarin 7-hydroxylation O-deethylation by human liver cytochrome P450 enzymes". J. Chromatoger. B., 1999, 721, 13-19.

9. Izquierfo, M. E. F.; Granados, J. Q.; Mir, V. M.; Martinez, M. C. L. "Comparison of methods for determining coumarins in distilled beverages". Food Chem., 2000, 70, 251-258.

10. Trenor, S. R.; Shultz, A. R.; Love, B. J.; Long, T. E. "Coumarins in polymers: from light harvesting to photo-crosslinkable tissue scaffolds". Chem. Rev., 2004, 104, 3059-3078.

11. Di Braccio, M.; Grossi, G.; Roma, G.; Marzano, C.; Bacccichetti, F.; Simonato, M.; Bordin, F. "Pyran derivatives: Part $\mathrm{XXI}$. Antiproliferative and cytotoxic properties of novel $\mathrm{N}$-substituted 4-aminocoumarins, their benzo-fused derivatives, and some related 2-aminochromones" .F. II Farmaco., 2003, 58, 1083.

12. Roma, G.; Di Braccio, M.; Carrieri, A.; Grossi, G.; Leoncini, G.; Signorello, M. G.; Carotti, A. "Coumarin, chromone, and $4(3 H)$-pyrimidinone novel bicyclic and tricyclic derivatives as antiplatelet agents: synthesis, biological evaluation, and comparative molecular field analysis". Bioorg Med Chem., 2003, 11, 123.

13. El-Saghier, A. M. M.; Naili, M. B.; Rammash, B. Kh.; Saleh, N. A.; Kreddanc, K. M. " Synthesis and antibacterial

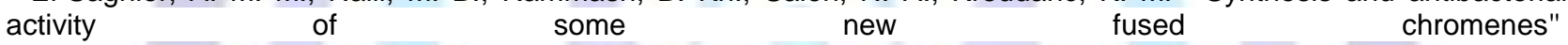
Arkivoc., 2007, (xvi), 83-91.

14. Kokotos, G.; Theodorou, V.; Tzougraki Dieter, C.; Deforce, L. D.; Van den Eeckhout, E. G. Bioorg. Med. Chem. Lett., 1998, 7, 2165.

15. Jarrahpour, A. A.; Jalbout, A. F.; Rezaei, S.; and Trzaskowski, B. Malbank., 2006, M455.

16. Taggi, A. E.; Hafez, A. M.; Wack, H.; Young, B.; Ferraris, D.; Lectka, T. J. Am. Chem. Soc., 2002, $124,6626$.

17. Jarrahpour, A. A.; Shekarriz, M.; Taslimi, A. "Synthesis and Antimicrobial Activity of Some New Sugar-Based Monocyclic $\beta$-Lactams". Molecules. 2004, 9, 29-38.

18. Chohan, Z. H.; Arif, M.; Shafiq, Z.; Yaqub, M.; Supuran, C. T. J. Enzyme Inhib Med Chem., 2006, 21(1), 95-103.

19. Ren, S.; Wang, R.; Komatsu, K.; Bonaz-Krause, P.; Zyrianov, Y.; McKenna, C. E.; Cipke, C.; Tokes, Z. A.; Lien, E. J. "Synthesis, Biological Evaluation, and Quantitative Structure-Activity Relationship Analysis of New Schiff Bases of Hydroxysemicarbazide as Potential Antitumor Agents". J Med Chem., 2002, 45(2), 410-419.

20. Al-Haiza, M. A.; Mostafa, M. S.; El-Kady, M. Y. "Preparation of Some New Coumarin Derivatives with Biological Activity". Sci. J. of king Faisal University (Basic and Applied Science)., 2005, 6(1), 1426.

21. Haitham, D. H." Synthesis and Characterization of New Seven-Membered Heterocyclic Compounds from Reaction of New Schiff-Bases with Maleic and Phthalic anhydrides". National J. Chem., 2011, 41, 77-89.

22. Abdul Amir H. K.; Ahmed A. Al-Amiery.; Ahmed Y. M.; Abu Bakar M. "The Antioxidant Activity of New Coumarin Derivatives ".Int J. Mol Sci., 2011, 12, 5747-5761.

23. Mukul Sharma, M.; Manohar, S.; Rawat, S. "W. Lewis Acid Catalyzed Synthesis of 1-Aryl-1,2-dihydro-naphtho[1,2e][1,3]oxazin-3-ones under Solvent Free Conditions". J. Heterocyclic Chem., 2012, 49(3), 589-595.

24. Zhang, Z.; Wang, S.; Zhang, G. "Facile synthesis of 5-aryl-1-[(arylamino) methyl] - 1, 3, 5-triazinane-2-thiones". J. Heterocyclic Chem., 2012, 49(2), 433-437.

25. Mashkouri, S.; Naimi-Jamala, M. R.; Sharifi, A. "Solvent-Free Synthesis of 2-Amino-4H-Chromenes Catalyzed by Sodium Carbonate". 12th International Electronic Conference on synthetic organic chemistry., 2008, (Ecsoc-12), 1-30.

26. Bi-HuiXu, Man-Su Tu.; Yin-Ping , Liu.; Jiang ,Bo.; Xing-Hang, Wang.; and Shu-Jiang ,Tu. " Microwave-Assisted ThreeComponent Reactions Leading to Pyrano-Fused Pyrazolo[3,4-b]pyridines". J. Het Chem., 2014, 51(6), $1591-1594$. 
27. Mei-Mei .Z .; Wei W .; Xiang-Shan W. "Three-Component One-Pot Synthesis of Indolo[3,4-a]acridine Derivatives with High Regioselectivity under Catalyst-Free Conditions". J. Heterocyclic Chem., (2014), 51, E349.

28. Ain Khan, M.; Gemal , A. L. " Synthesis of 5[H] Benzopyrano[3,4-b]pyridine-5-one and its derivatives". J. Heterocyclic Chem., 1977, 14, 1009.

29. Singh , I.; Kaur, H.; Kumar, S.; Kumar, A. " Synthesis of New Coumarin Derivatives as Antibacterial Agents". Inter. J. Chem. Tech Res. 2010, 2(3), 1745-1752.

30. Kaur,H.; Kumar,S.; Singh, I.; Kumar, A. " Synthesis, characterization and antibacterial activity of various substituted oxadiazolylpyrazolinyl/isoxazolinylcoumarin derivatives". Inter. J. Ph. Sc Res., 2010, 1(1), 58-65.

31. Boakye-Gyasi, E.; Woode, E.; Ainooson, GK.; Obiri, DD.; Ansah, C.; Duwejua, M.; Donkoh, A. "Anti-Inflammatory and antipyretic effects of an ethanolic extract of Palisotahirsuta K. Schum roots". African J. Ph .Ph., 2008, 2(9): 191-199.

32. Salvemini , D.; Wang, S-Q.; Wyatt, PS.; Bourdon, DM.; Marino, MH.; Manning, PT.; Currie, MG. "Nitric oxide: a key mediator in the early and late phase of carrageenan-induced rat paw inflammation". British J.Ph.1996., 118, 829-838.

33. Posadas, I.; Bucci, M.; Roviezzo, F.; Rossi, A.; Parente, L.; Sautebin ,L.; Cirino, G.; "Carrageenan-induced mousepaw oedema is biphasic, age-weight dependent anddisplays differential nitric oxide cyclooxygenase-2 expression" .British $\mathrm{J}$. Ph., 2004, 142, 331-338.

34. Sahoo, S.S.; Shukla, S.; Nandy, S.; and Sahoo, H.B. "Synthesis of novel coumarin derivatives and its biological evaluations". Eur. J. Exp. Bio., 2012, 2 (4), 899-908.

35. Hadji , pavlou-Litina D . J.; Litinas KE, Kontogiorgis, C. "The Anti-inflammatory Effect of Coumarin and its Derivatives". Anti-Inflammatory \& Anti-Allergy Agents in Medicinal Chemistry., 2007, 6(4):293-306

36. Kim, K.; Yang, H.; Ko, S.; Ko, Y.; Kim, E.; Roh, SW.; Ko, E.; Ahn, G.; Heo, S.; Jeon, Y.; Yoon, W.; Hyun, C.; Kim, D. "6,7Dimethoxy-4-methylcoumarin suppresses pro-inflamm atory mediator expression through inactivation of the NF-KB and MAPK pathways in LPS-induced RAW 264.7 cells". EXCLI. J., 2014, 13:792-800.

37. Cuzzocrea, S.; Sautebin, L.; De Sarro, G.; Costantino, G.;Rombola, L.; Mazzon, E.; Lalenti, A.; De Sarro, A.; Ciliberto,G.; Di Rosa, M.; Caputi, AP.; Thiemermann, CH. "Role of IL-6 in the pleurisy and lung injury caused by carrageenan". J. Imm., 1999, 163, 5094-5104

38. Winter, C. A; Winter, E. A; Nuss, G. W. J. Ph. Exp. Therapy., 1963, 141,369.

39. Adedapo, A. A.; Sofidiya, MO.; Afolayan, A. J. Rev. Biol. Trop., 2009, 57, 1193-1200. 